\title{
Training Project Management Complexity in Postgraduate And Continuing Education Programs: A Learning Strategy in The Eshe (European Space of Higher Education) Framework
}

DOI 10.5592/otmcj.2011.2.5 Research paper

\author{
Jesús Mtnez-Almela \\ Universidad Politécnica de Valencia-UPV, \\ Spain \\ jma@bioagroprojects.com
}

Ignacio de los Rios
Universidad Politécnica de Madrid-UPM,
Spain
Ignacio.delosrios@upm.es

THE OBJECTIVE OF THIS PAPER IS TO ADDRESS THE METHODOLOGICAL PROCESS OF A TEACHING STRATEGY FOR TRAINING PROJECT MANAGEMENT COMPLEXITY IN POSTGRADUATE PROGRAMS. The proposal is made up of different methods -intuitive, comparative, deductive, case study, problem-solving Project-Based Learning - and different activities inside and outside the classroom. This integration of methods motivated the current use of the concept of "learning strategy". The strategy has two phases: firstly, the integration of the competences - technical, behavioral and contextual-in real projects; and secondly, the learning activity was oriented in upper level of knowledge, the evaluating the complexity for projects management in real situations. Both the competences in the learning strategy and the Project Complexity Evaluation are based on the ICB of IPMA. The learning strategy is applied in an international Postgraduate Program -Erasmus Mundus Master of Science- with the participation of five Universities of the European Union. This master program is fruit of a cooperative experience from one Educative Innovation Group of the UPM -GIE-Project-, two Research Groups of the UPM and the collaboration with other external agents to the university. Some reflections on the experience and the main success factors in the learning strategy were presented in the paper.

\section{INTRODUCTION}

Currently, we are involved in a widereaching process of reflection and change oriented toward promoting a qualitative leap in the educational model of the universities of the European Union stemming from different agreements reached in the EU to construct a
European Higher Education Area (EHEA) to be the basis of a new knowledgebased economy that responds to the challenges of globalization and to the complexity of the situations (European Council, 2000; European Commission, 2003a). The Bologna Declaration (European Commission, 1999) is particularly 
a key document, which marks a turning point in the development of European higher education. It was signed by 29 countries which assume the challenge to attain the Declaration's objectives and, to that end, engage in coordinating their policies.

This new challenge demands new teaching innovation models, based on the competences and in the aptitudes, and required new designs of the educative programs, new objectives and new teaching and learning methods. In this challenge context, arises the concept of "lifelong learning" (European Council, 2000; European Commission, 2001; 2003b) understood like all learning activity undertaken throughout life with the objective to improve the knowledge, the competences and the aptitudes with a personal, civic, social or employability dimension (European Commission, 2000). The concept is closely linked to continuous education and continuing professional development.

In numerous disciplines -not only techniques-specific skills and competences on the project team are necessary for the solution of problems, and to be able to transform the ideas into a reality. These skills and profiles of the project team need to include: the ability to work in multidisciplinary teams, imagination and creativity, the ability to think in terms of a long-term future, the ability to stimulate dialogue, and often radical thought, amongst all individuals involved in the process of foresight, the ability manage complex projects; the ability to mediate diplomatically between different interest groups and stakeholders without losing sight of the objectives of the exercise, the flexibility to adapt the process to needs (European Commission, 2005).

Technological, economic, social, cultural and political changes define new profiles in view of what the enterprises need from their professionals. In a so- ciety characterized by a wide range of approaches, aspects never before considered are being discovered. To solve the enterprises' problems, technology is not enough; rather more humanism is necessary (Llano, 1995); therefore arises, the increasing importance of behavioral competences to manage the complexity (Winter et al, 2006).

Teaching and learning was identified as a major theme in the international debate on re-thinking project management (Cicmil et al, 2006; Winter, Smith, Morris, \& Cicmil, 2006). Understanding the student experience will enable institutions of learning to address pedagogic and education factors within project management more effectively in the future (Ojiako et al, 2011). Institutions for Project management education and the universities are increasingly facing new challenges brought on by a number of major disruptive drivers and methodological changes, with approaches focus on developing behavioral competences (European Commission, 2005). It's for that reason that the professional competences - aptitudes and abilities- according to the demand of the society, constitute a key aspect for the design of all education programs.

\section{Competences for project management complexity}

Competence is an amplification of the concept of ability and qualification resulting from the rapid technical evolution in the organization of work and planning activities (Grootings, 1994). The competence of professional action (Delcourt, 1999) is thus the sum of the competences essential to carrying out a professional task well (Echevarria, 2002). In the international tendencies in Project management, the competence development approaches is seen as a key element and include concepts like benchmarking, maturity, certification, and learning and knowledge management (Winter et al, 2006).
Project management researches (Turner, 1996) have put more emphasis on the rational models - "hard systems" models- focused on the technical project dimension, especially in the planning and the control (Morris, 2002; Checkland, 1989; Winch, 2004; Yeo, 1993). Other researches prove the importance of social sciences in the models of projects management, integrating the behavioral competences of the organizations (Hodgson, 2002; Cazorla et al, 2010; Lawrence \& Lorsch, 1967; Galbraith, 1973; Winch, 2004; Cicmil \& Marshall, 2005; Cooke-Davies, 2004; Lawrence \& Lorsch, 1967; Hodgson, 2002; Gareis, 2010). In addition, other research recognizes the importance of the models of projects management integrate the contextual competences to consider the exogenous factors that influence in the projects (Stinchcombe \& Heimer, 1985; Morris \& Hough, 1987; Miller \& Lessard, 2001; Flyvbjerg, 2002; Morris \& Pinto, 2004; Davies \& Hobday, 2005).

On the other hand, the importance of complexity to the project management process is widely acknowledged in the international literature by diverse reasons (Baccarini, 1996): to helps determine planning, coordination and control requirements (Bubshait \& Selen, 1995); project complexity hinders the clear identification of goals and objectives of major projects (Morris \& Hough, 1987); complexity is an important criteria in the selection of an appropriate project organizational form (Bennett, 1991); project complexity influences the selection of project inputs (Baccarini, 1996); complexity is frequently used as a criteria in the selection of a suitable project procurement arrangement (CIOB, 1991); complexity affects the project objectives of time, cost and quality (Bennett \& Fine, 1980). In the case of sustainable rural development projects, the numerous socials interactions (Cazorla et al, 2005) and the complexity of the social networks (Butts, 2001), its usually cause of difficult and complex situations. 


\section{Social dimension of complexity in project management}

Faced with the evidence, the new contexts required training project management professionals will be more competent at handling complex situations. According to Winter et al (Winter et al 2006) «we need to develop new models and theories which recognize and illuminate the complexity of projects - new ontologies and epistemologies - which extend and enrich our understanding of the actual reality of projects and project management practice».

As previously mentioned, this need requires reconsidering the project cycle from a more social and human perspective (Linehan \& Kavanagh, 2004; Hodgson \& Cicmil, 2006). Definitively, in that moment of deep changes like we are, and due to the complexity of the situations, the projects management's role for the next years should be including a strong social component. The technical and isolated work from a design consultancy outside the reality should be substitute by multidisciplinary team's project with the ability addressing complex cross-cutting social issues as members of different professional and occupational groups, and with the ability manage complex situations from different points of view (Cazorla et al, 2010). This social and multidisciplinary perspective, demands leadership models (Uhl-Bien et al, 2007; Müller \& Turner, 2010) aligned with the personal values (Selznick, 1957) and with the role of project management (López et $a l, 2009)$. This required increasing the ethical dimension that includes the conducts and the moral behaviors of the professionals and the interested parties (IPMA, 2010).

This paper presents the fundaments of a cooperative teaching methodology which integrate the competences of project management-according to the Internacional Project Management As- sociation IPMA-, the scientific foundations of Project-Based Learning and the complexity framework for performance based competency standards for Global Project Managers (GAPPS, 2007). The methodology is developed -like an innovative pilot experience- and covers both undergraduate and graduate levels, an entire educational strategy completely adapted to EHEA.

\section{Research methodology}

The results of this research are based on the implementation of one strategy for the competence development of the people, through a Educational Innovation Program (EIP). This strategy its part of the adaptation process to the EHEA in the UPM University. In the previous context of change, the EIP has its origins in the policies adopted by the UPM to promote, from Educational innovation, the teaching restructuring of university education as a strategic line of action of all the Technical Colleges of the Technical University of Madrid (UPM, 2006). For this restructuring, the Technical University of Madrid, within the General Education Quality Project, decides as the main line of action, the promotion and subsequent acknowledgement of "Educational Innovation Groups". This body is established as an original investment in the current university scene. Within this framework the Government Council of the UPM approved in May 2005 the Institutional Quality Programme in which the first pilot announcement of Educational Innovation Projects was included in the Educational Innovation Programme. After this announcement, the EIG-Project is approved as a group set up by people that show a career, experience, training and a future project of sufficient consistency, specifically in the fields of engineering and project management. EIG-Project starts with the main objective of conceiving a new teaching dimension around Projects as educational elements suitable to generate an early professional experience and training from competences.

In this framework, EIG-Project use the Project-Based Learning (PBL) (Gijselaers, 1996; Johnson, 1999; Padmanadhan \& Katti, 2002; Chinnowsky et al, 2006; De los Ríos et al, 2010), as the most powerful method to obtain an effective competency-based teaching (Mulcahy, 2000; Parsons et al, 2005; Kelly, 2007). Following the trends in psychology of knowledge, PBL is grounded in the belief that humans construct new knowledge over a base of what we already know (Gijselaers, 1996) and of what we have experienced, which we make available through active participation and interaction with others.

In order to obtain the strategic objective to develop the competences from the perspective of the international standard (GAPPS, 2007), the EIP has different phases: the Educational Innovation Projects. These El Projects may be renewed annually subject to satisfactory progress and his results. The renovation requires the evaluation of the projects EIP, on the part of an independent Advisory Committee, incorporating processes of learning with the application of participative techniques. The judicious use of an external advisory committee, composed of consultants from outside the program EIP and as part of a participatory learning process (Whyte, 1991; Patton, 1997), its needed for a renovation project and can be helpful in providing independent program evaluation.

This EIP approach has also enabled achieve the following objectives: a) making knowledge and experience of those involved the main source of information for program management (Argyris \& Schön, 1978; Turner et al, 1996) (Nikolaou et al, 2007); b) encourage the learning of all actors (Rondinelli, 1993; Preskill \& Torres, 1999); c) focus changes from the beneficiaries of the actions 
viewpoint (Korten, 1980; Uphoff, 1990; Hughes, 2007; Nieminen \& Lehtonen, 2008). The following scheme (Figure 1) shows to the process followed in the EIP implementation according to the programs management phases: (Pellegrinelli, 1997): (1) Initiation, (2) Definition and Planning, (3) Projects Delivery and (4) Renewal, (5) dissolution. around the Project Management Competences (De los Ríos et al, 2010). This methodology integrates teaching and research in a four levels scheme, giving to students a gradual and growing formation in the competence fields. The process begins at the undergraduate level courses in Project $4^{\text {th }}$ and $5^{\text {th }}$ year - developed from (PBL), to end of

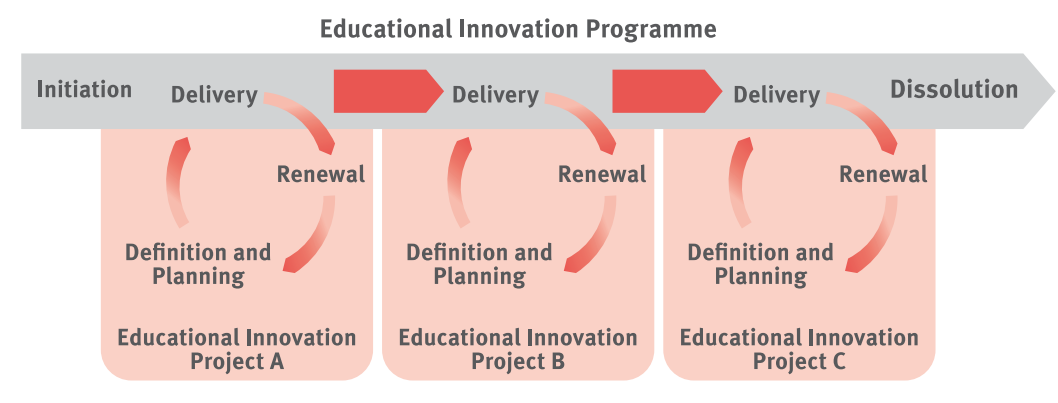

Figure 1. Phases of the Programme of Educational Innovation. GESPLAN-UPM

The EIP main characters fall into two recognized and regulated work structures in the UPM: Educational Innovation Group (GIE-Project) and a Group $\mathrm{I}+\mathrm{D}+\mathrm{i}$ (GESPLAN). On the one hand, GIE-Project, has as main goal the development of individuals skills, from the Project-Based Learning PBL -Thesis and Master Thesis Project- like an appropriate educational tool to generate professional advance experience strengthening cooperative learning (Bartkus, 2001; Hackett et al, 1998) and gradually address the IPMA project management competence elements (De los Ríos et al, 2008). Moreover, the Research Group on Planning and Sustainable Management of Local Rural Development (GESPLAN), develops lines of research applied in the context of Planning and Management Project of Local Rural Development, which complements the teach work and extends postgraduate studies.

Many teachers and researchers involved in the Programme of Educational Innovation belong to both structures, facilitating the teaching-research integration within a learning strategy subject projects. As training goes this way, it increases the activities complexity, to graduate level: Erasmus Mundus International Master- REG IPMA (IPMA Registed Educational Programme)- and doctoral linked to a Master of research officially recognized. Since 2006 the strategy is complemented by a graduate seminar "Project Management" in collaboration with projects engineering companies and supported by the Spanish Association of Project Engineering (AEIPRO). While in level grade gain more weight the technical competence twenty elements (IPMA, 2010) essentials for project management, at the graduate level is more intensely considered the competence contextual and behavior elements, and also increase the complexity of the activities.

The PIE has a variety of educational methods: intuitive, comparative, deductive, case studies, problem solving and various activities like, group activities, cooperative learning, both inside and outside the classroom, tutoring virtual and presence, project exhibitions, competition project teams, etc.-
, spanning from undergraduate and graduate levels. All these activities are part of the Project-Based Learning fundamentals (Gijselaers, 1996; Johnson, 1999; Padmanadhan \& Katti, 2002; Chinnowsky et al, 2006; De los Ríos, et al., 2010) as the best means to achieve effective competency-based education (Mulcahy, 2000; Parsons et al, 2005; Kelly, 2007) integrating knowledge, skills and values.

\section{Educational Innovation Strategy}

Figure 2 shows all the actors involved and the basic work methodology to implement projects with students. First, the planning team- GESPLAN -is situated on an intermediate position between the project client -Technical team of the General Directorate of Rural Development from the Community of Madrid, and the project beneficiaries - population living in rural areas. Secondly, students are inserted into this framework to participate in a learning process and solve real problems in a team project. During this process the students are enriched with external knowledge extracted from the direct contact with various people with whom they interact. The participation of local people in the process of project formulation and adequacy of policies plans for local and rural development programs in Madrid are fundamental criteria for these projects. These relationships and complementary information, allow students to enrich their knowledge base to build up new knowledge. The innovation strategy extends to postgraduate education, including other actors- national and international- to be coordinated and tutored by teachers from GESPLAN Group (De los Ríos et al, 2010). 


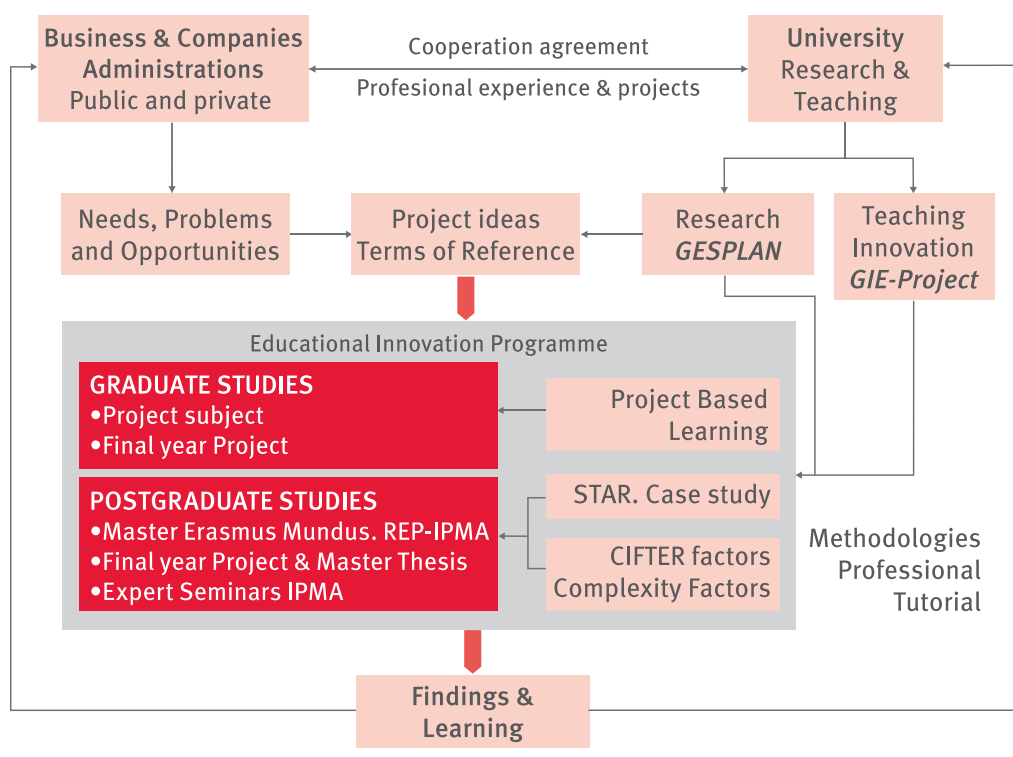

Figure 2. Educational strategy within Educational Innovation Project (PIE)

\section{Undergraduate activities: Project-Based Learning}

At the graduate level, educational activities are based in PBL method. At this level the methodology of learning consists that students in small groups, planning, design and evaluate a project that meets real needs for a real client private or public- coordinated by teachers of Projects lecture. In this process of approximation to reality group activities and interactive workshops are made in class for the course project using active methods (Johnson, 1999) to get the direct involvement of students, similar to a real professional project. In these sessions the teacher acts as counselor for the tasks performed by the students and the learning incentive for active absorption of knowledge. The active method of learning by doing (Hackett et al, 1998; Johnson, 1999; Bartkus, 2001;) is presented in the area of project management with particular relevance, with a huge potential for originality and creativity development that can be fully assembled with the scientific and technical knowledge. At the end of the lecture period, different groups of students must present and defend their projects with teachers and managers involved.
In this learning process activities are integrated to the knowledge development of 46 competence elements necessary for project management and problem solving. Although there is more relevance for technical competence (IPMA, 2010) essential for project management, there are also considered some of contextual and behavioral competence elements. During this activity, which have been defined as "early professional experience" (Cazorla \& De los Rios, 1998) is part of the idea of learning by doing, learn from

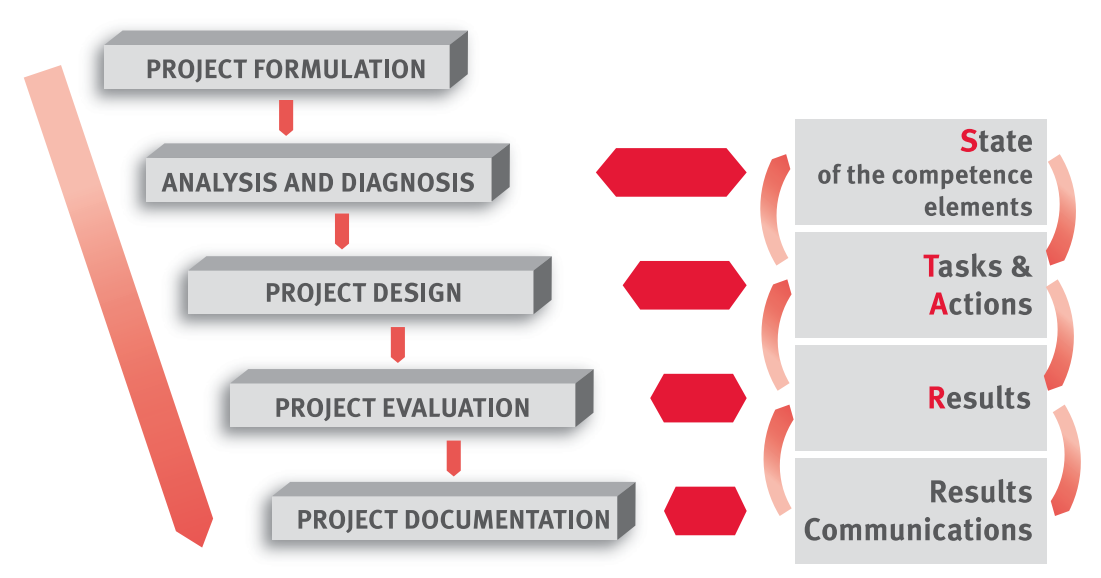

Figure 3. Project Phases course with the PBL approach reality and extract from there adequate knowledge. Participation in projects with real content, which respond to real needs, gives students the opportunity to leave the classroom, get in contact with external agents to solve real problems. This characteristic is a dynamic element for the educational process where students learn to see how organizations-projects customers (De los Rios et al, 2010).

Learning respond to a logical structure according to the methodology phases for formulating and evaluating projects (Figure 3). The development of the Projects lectures is basically a learning process designed to teach methodologies, which have an organic process where phases and concepts are linked to each other. This logical process follows the following phases (De los Rios et al, 2008).

On the preparation stage for the formulation of project (1) the task force are set, terms of reference are drawn up and work plan prepared. Subsequently, the analysis and diagnosis phase (2) students role play the different aspects of the specific situation of the project team. During this phase, students receive training in research techniques and analysis for the collection and examination of data (analysis) 
and qualitative and quantitative identify the main causes of the situation (diagnosis). At the end of this phase, all teams must identify possible proposals to improve the current situation and to answer the question "has been understood what needs to be done in the project situation?

Taking as reference conclusions drawn during the analysis and diagnosis phase, teams proceed to the project design phase (3) for a more detailed and precise elaboration of the project to develop an investment proposal. During this phase, students receive training in design and planning tools in order to address the technical specifications of the project components. Although the specific level of detail depends on the nature of the project, all teams should proceed with emphasis on verifying systems, products and technologies viability. They must also define the project organization structure, its time programming, resources management, and estimate costs and benefits. The main question that teams must meet at the end of this phase is $i$ are we sure know how to make the project work?.

After completing and documenting the previous phase, multicriteria assessment (4) examine the effects and impacts that the project could generate when implemented. Results of this phase should guide the technological, economic, financial, social and environmental viability of the project. During this phase, the following elements of competence are specifically addressed: resources, cost and finance, business, safety and environment and ethics. Final phase is project documentation (5), where deliverables and final report are integrated. Synthesis capability is critical to knowing how to communicate properly, to teachers, external stakeholders and colleagues the relevant information, and issue an opinion on the project.

\section{Activity at the graduate level: STAR method}

At postgraduate level students tend to have a higher general knowledge of all competence elements, and are trained on more complex activities and learning level. At this level educational activities and instruments used have two phases: a) STAR method using the case method, b) cooperative learning with the instrument CIFTER.

\section{Graduate level Stage 1: STAR Method}

On a first phase, within the lectures of Design and Project Management, the case method is used as a learning tool to consider on a particular experience. The structure of the cases follows the method named STAR, used by AEIPRO in the process of competence certification of IPMA (AEIPRO, 2009). Using this method, the analysis of the IPMA competence elements is implemented in a real case, considering the following steps: a) describe a project situation (S) in relation to the competence elements, b) indicate the tasks ( $T$ ) and specify the activities (A) proposed to be done in that situation, and d) specify the possible results ( $R$ ) to achieve to improve the situation. By using this process, at this first phase on the graduate level, it is intended to train students on two main aspects: thinking about implementing a project report by integrating IPMA competences, and master how to communicate the interaction among competence elements.

\section{Graduate level Stage 2: CIFTER.}

Within the same educational program, and on a second phase, students perform a series of cooperative learning activities (Johnson, 1999) to assess the complexity of the project using the instrument CIFTER -Crawford-Ishikura Factor Table for Evaluating Roles- under concept of the Global Alliance for Project Performance Standards (GAPPS, 2007). In these sessions, same projects that have been considered in the first phase using the STAR method are analyzed, so that students already have prior knowledge and results to assess the complexity. In addition to cooperative learning among team members, in the sessions comparisons and conclusions are drawed jointly, to promote the interdependence of group learning.

According Crawford-Ishikura Factor Table for Evaluating Roles (CIFTER) there are seven CIFTER Factors which together define a project's management complexity. The CIFTER identifies seven factors that affect the complexity of a project management: (1) overall stability of the project context, (2) number of distinct disciplines, methods, approaches or involved in performing the project, (3) magnitude of legal, social, or environmental implications from performing the project, (4) overall expected financial impact (positive or negative) on the project's stakeholders; (5) strategic importance of the project for the organisation or involved organisations (6) stakeholder cohesion regarding the characteristics of the product of the project; (7) number and variety of interfaces between the project and other organisational entities (GAPPS, 2007). Each factor is rated from 1 to 4 using a qualitative point scale, and the factors are totaled complexity management to produce a rating for the project.

In addition to knowing, understanding and analyzing the CIFTER's factors activities are carried out using the guidelines for the evaluation of the complexity in projects according AEIPRO, considering new approaches and complementary concepts (Table 1) (IPMA, 2008). 


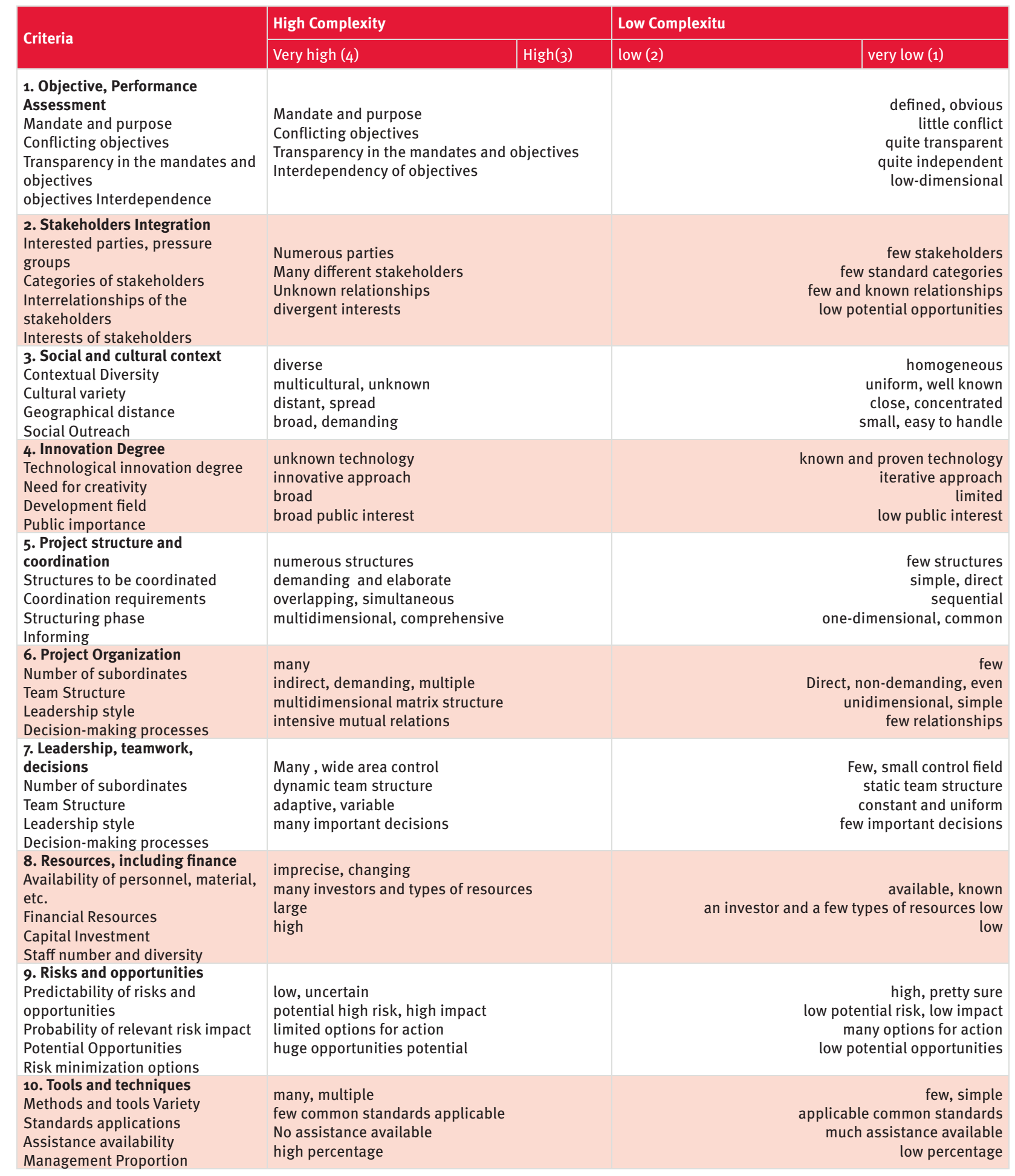

Table 1: The CIFTER's factors

Findings and results: Implementation of the model to MIDRL

This section describes the model application in the specific case of international competition on "Project Management of Local Rural Development” as the competences system of IPMA. This application is made in the Master-Local Rural Development Project Management Agris Mundus, 6o ECTS, which is inserted since 2005 in EEES like Erasmus Mundus Master of Science of the EU. In addition to the UPM, INFODAL and the Higher Council for Scientific Research ( $\mathrm{CSCl}$ ), take part in the Program Projects Companies -IDOM and EPTISA international- and five universities of the European Union -CNEARC Agropolis Montpellier (France), Wageningen University and Research Centre (Holland), 
University of Copenhagen KVL (Denmark), University of Cork (Ireland), University of Catania (Italy)-. The Program international dimension is reinforced for two reasons: first for being part of the International Association NATURA “European Network of Agricultural" related to rural development projects. Moreover, since 2006, the program reinforces its size internationally through the "Action 3 " of the Erasmus Mundus- establishing a partnership with 8 higher education centers from third countries of Africa, Asia and Latin America. This action results in a greater openness to the world, strengthening its global presence and establishing partnerships with higher education institutions in third countries. Such partnerships encourage students and academics external mobility making the AgrisMundus Sustainable Development Alliance.

Later, after four years of refinement to the integration of IPMA competences, the programme is presented for verification at the end of 2008, and mid 2009 the programme gets its Registration of Competence Development Programmes. This international program is inserted since 2005 in an UPM Educational Innovation Program (EIP) as a reference point of new perspective for developing competencies, according to IPMA-NCB, for project management teaching in engineering higher education (De los Ríos-Carmenado, I.; Ortiz, I.; Díaz-Puente, J., 2009). This model is applied from the two structures above -Educational Innovation Groups and $\mathrm{R}+\mathrm{D}+\mathrm{i}-$ recognized and supported by UPM, incorporating teachers and researchers. In order to facilitate and to make viable the process of establishment of the model, among the coordinators of the teams of the PIE, there are Managers and Assistant Managers of the Colleges, as members of the Academic Committees of the new Degree and Postgraduate qualifications to the ESHE, as well as with members of the Educational Innovation Committee of the UPM responsible for supporting new educational methodologies based on competences and aptitudes. The figures show moments of one of the workshops, as a mean for integration of the IPMA competences within the framework of the ESHE establishment process (De los Ríos et al, 2010).
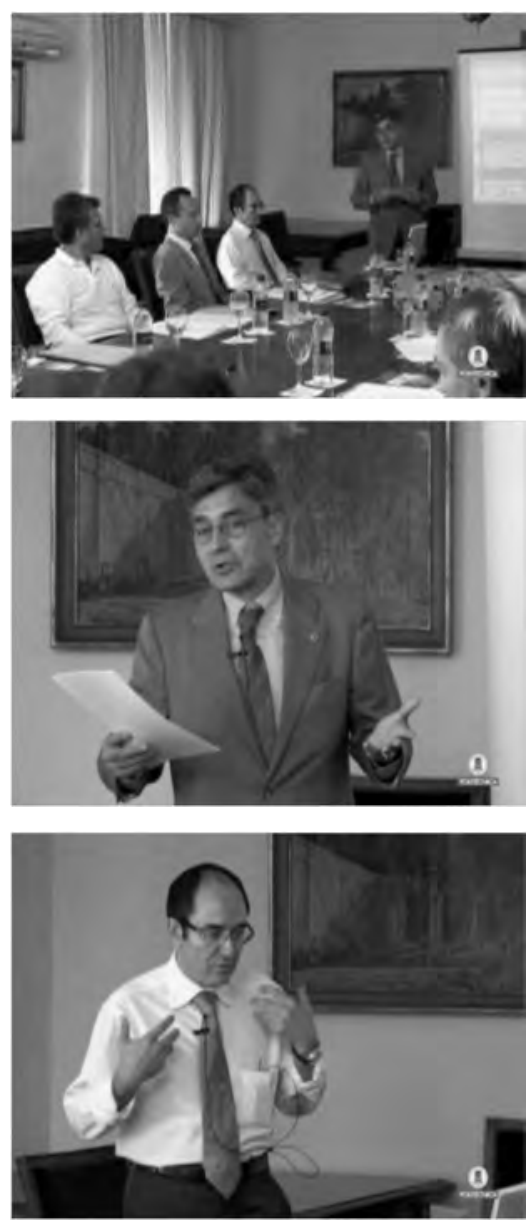

Figure 4: Expert-Multidisciplinary Workshop on concepts of the IPMA model

\section{Objectives and programme features}

The overall objective of the program is designed to validate the individuals' competences in their knowledge, experience and attitudes to the Project Management and Rural Development Programs-Local within the standards of the International Project Management Association (IPMA). The program features stem from the criteria of the Erasmus Mundus Programmes. It is therefore a cooperation and mobility programme in higher education, with the aim of improving the quality of European higher education and promotes intercultural understanding through cooperation with third countries. With Erasmus Mundus Programme is strengthened European cooperation and international links in higher education in the field of Project Management and Rural Development Programs-Local. The MIDR-AM is a master programme open to any professional interested in the management of development projects, which is inserted into the international arena.

From the academics years 2004-05 to 2009-10, 137 students from 29 different countries have been trained with very diverse training (Figure 5). In the program, in addition to UPM, INFODAL and the Higher Council for Scientific Research $(\mathrm{CSCl})$, are involved five other universities in the European Union and eight universities from outside the European Union, Africa, Asia and Latin America.
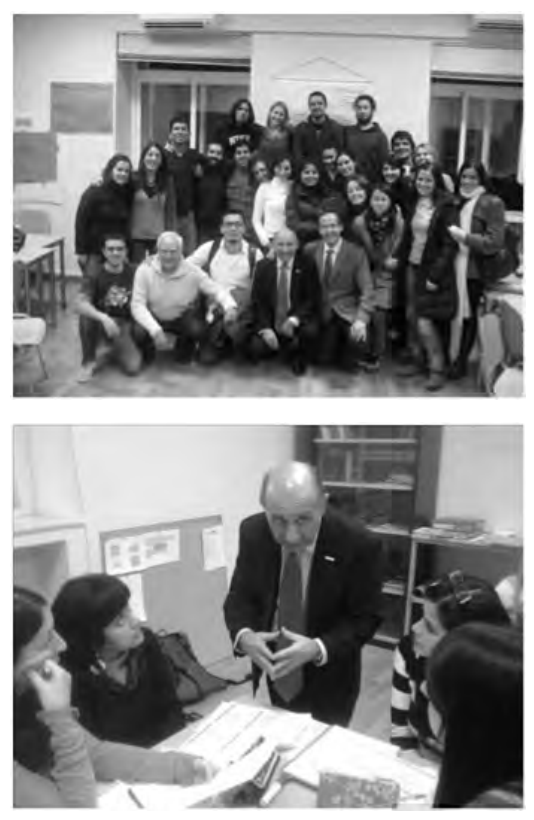

Figure 5: Masters' Workshop with Dr. Hans Knoepfel

The PBL methodology has evolved through collaboration agreements between UPM and public and private institutions for the implementation of integrated rural development-local projects. These cooperation agreements 
have been the basis for consolidating an approach to Project-Based Learning $(\mathrm{PBL})$ that has developed to adapt the methodological issues in teaching to real problems. The MIDRL program's learning activities begin with an activity of competences self-assessment (AEIPRO, 2009) by students, using the same questionnaire as requested in the IPMA certification process. This activity information is a key concept to guide the development of learning activities. The following charts show the competence average performance at the start of graduate school. The data show the value, -between 1 and 4- of the knowledge and experience to each of the elements of contextual and technical competences. The results correspond to the logic of the developed methodological strategy, as the grade level activities focus on developing more technical competences (IPMA, 2010), essential for project management. Graduate levels, is considered more intense learning activities to develop contextual and behavioural competences, also increasing the complexity of the tasks. For techni- cal competences, many of the elements, -teamwork, problem solving, communication, cost and funding, resources, information and documentation, project organization-, are above average. However there are still many elements that require greater learning.

In assessing contextual competences

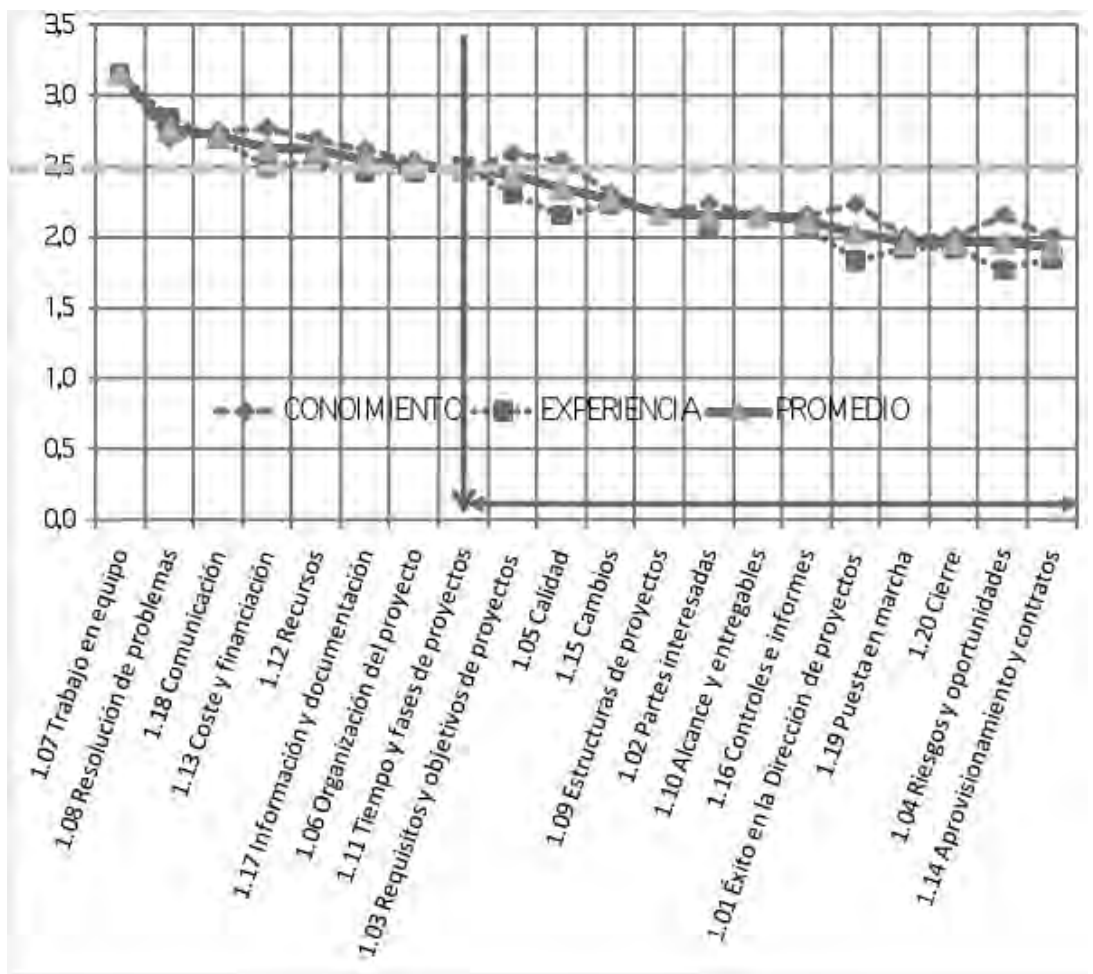

Figure 7: Self-assessment results of the contextual competence at the beginning of MIDRL

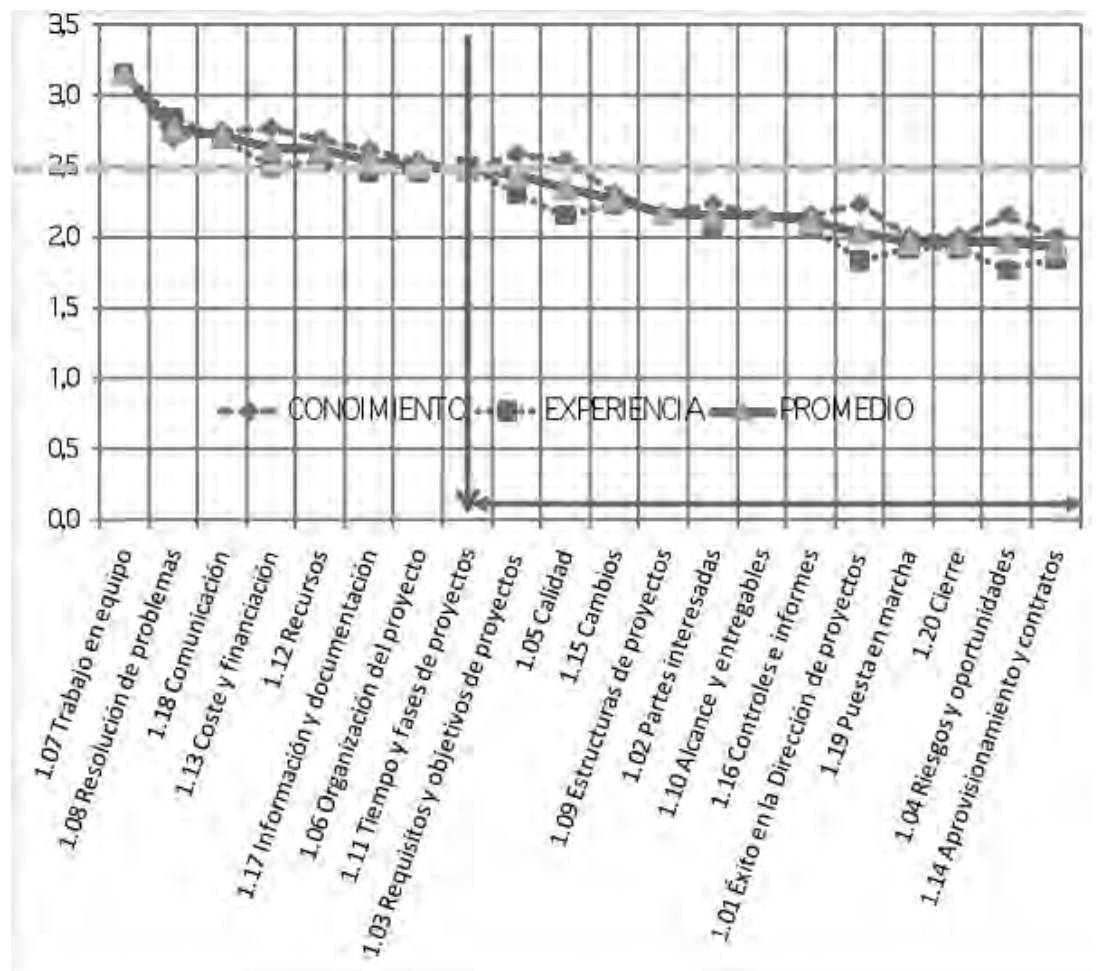

Figure 6: Assessment results of the technical competences at the beginning of MIDRL at the beginning of the program (Figure 6), only the security, hygiene and environment elements is above average, the rest of the competences are below. These contextual and behavioural elements, although there was an understanding of them, are regarded with greater intensity during the graduate level.

As for the problems encountered during this self-assessment phase, perhaps the most important are the students' difficulties to reflect on their own knowledge and experience. This activity has required a gradual effort to sensitize all teachers to see the need of change in the systems approach to evaluation, - competences assessment rather than knowledge- by the adaptation exigencies to the EHEA. Generally we can say that there are still some difficulties in incorporating assessment competence systems in the training programs. 


\section{Experience after using the STAR method of this case from the IPMA competences}

Through cases studies it examines the interactions of a large number of the NCB competence elements (AEIPRO, 2009). The experience so far tested with cases studies, following the PBL approach and STAR methodology, is ideally suited for students to link the technical and contextual elements to the rural development projects area, with the productive sector needs and the real problems at rural areas. From this formative point of view, personal competences also develop such as, teamwork, communication, leadership, commitment and motivation, self-control, self-confidence, openness, creativity, results orientation, efficiency, consultation, assessment values, adaptability and innovation in problem solving (De los Ríos et al, 2010).

Actual cases are chosen so that, there are situations to improve, from which competence elements are identifies, tasks arise and extracted relations between competence elements from three dimensions (technical, contextual and behavioural). The case used to analyse the complexity in the development projects management is the Leader Project, on which students are familiar with the conceptual basis and have previously visited some of the results during the field trip. The event takes place in two different contexts, Spain and Mexico, on the same conceptual complexity framework of the rural development projects. The project objectives focus on the Leader Programme implementation as an experimental form of addressing rural development, based on a territorial approach, creation of new local participative government structures and a decentralized management (Cazorla et al, 2005). The figure 8 show two conceptual frameworks developed by a students' group, representing, according to the evolution case information of a competence elements series applying the STAR methodology.
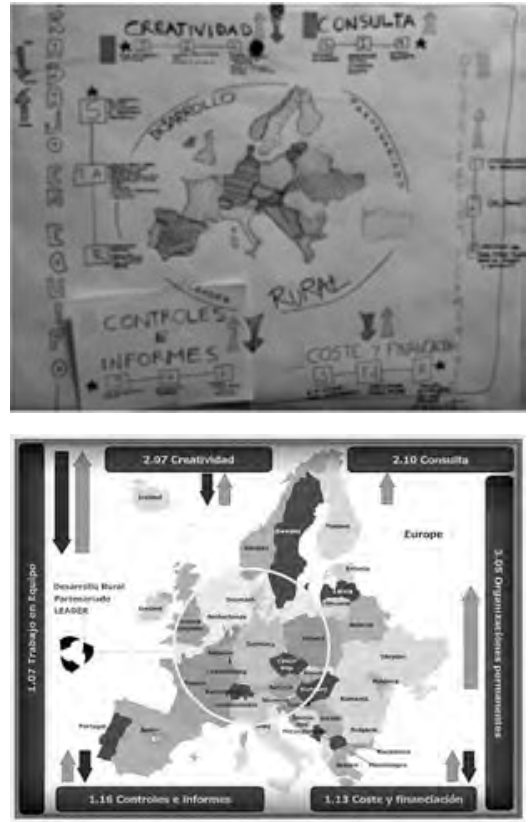

Figure 8: Conceptual maps of a students' group

From an initial situation with significant gaps in the "permanent organization" element, -there was no local organization to projects management, lack of participation for endogenous development and centralized the project decisionmaking- identifies a number of tasks and actions under the project, -leaders identification in the area, forming Local Action Groups, way of teamwork normalization, public-private links-, which provide a range of results $(R)$ that can

\begin{tabular}{|l|c|c|c|c|c|c|c|c|}
\hline & \multicolumn{4}{|c|}{$\begin{array}{c}\text { Case } \mathrm{n}^{0} \text { 1 } \\
\text { Leader Project Madrid }\end{array}$} & \multicolumn{4}{|c|}{ Case $\mathrm{n}^{0}$ 2 } \\
\hline & Leader Project Mexico \\
\hline Complexity Evaluation Factors & G1 & G2 & G3 & Average & G1 & G2 & G3 & Average \\
\hline C1. Objectives, outcomes & 2 & 3 & 2 & 2,33 & 2 & 3 & 2 & 2,33 \\
\hline C2. Stakeholders, integration & 3 & 3 & 3 & 3,00 & 4 & 4 & 3 & 3,67 \\
\hline C3. Socio cultural Context & 2 & 2 & 2 & 2,00 & 4 & 4 & 3 & 3,67 \\
\hline C4. Innovation Grade & 3 & 4 & 3 & 3,33 & 4 & 3 & 3 & 3,33 \\
\hline C5. Project structure, coordination needed & 3 & 3 & 2 & 2,67 & 4 & 3 & 4 & 3,67 \\
\hline C6. Project organization & 3 & 4 & 3 & 3,33 & 4 & 4 & 3 & 3,67 \\
\hline C7. Leadership, work team, decisions making & 3 & 3 & 3 & 3,00 & 4 & 4 & 3 & 3,67 \\
\hline C8. Resources & 2 & 3 & 2 & 2,33 & 3 & 3 & 3 & 3,00 \\
\hline C9. Risk and opportunities & 3 & 2 & 1 & 2,00 & 4 & 3 & 2 & 3,00 \\
\hline $\begin{array}{l}\text { C10. Methods, tools and management } \\
\text { techniques }\end{array}$ & 3 & 3 & 2 & 2,67 & 3 & 2 & 3 & 2,67 \\
\hline
\end{tabular}

Note: very high (4), high (3), low (2), very low (1)

Table 2: Assessments results of the project complexity by each team

verify and quantify -the territory operating agents are represented and carried out a collective strategy to have people with decision-making to manage the budget (GAL), companies start-ups that affect the endogenous development, decentralized project management, etc. .- Other competence elements which, in this case, are analysed and represented are: creativity, consultation, teamwork, cost and funding, monitoring and reporting.

In a second phase, inside the same Masters subject -Demonstration and Development Project Management-, as a specialized workshop, students complete a new cooperative learning process aimed to deepen the complexity of project management. For this activity, students use two instruments, the same case study previously discussed -Leader Project, and CIFTER -CrawfordIshikura Factor Table for Evaluating Roles (GAPPS, 2007)-. These instruments are made in work teams with cooperative learning (Hackett et al, 1998). With the results, each team prepares a report that is communicated orally and is the basis for the discussion of learning, joint discussions and exchanges. A comparison of team performance, increases learning, establishing interdependencies between results and conclu- 
sions jointly developed, which affect the development of personal skills (Bartkus, 2001). The graph and table show the results of the evaluations of two projects for each team, according to the factors considered in the complexity evaluation.

There highlights similarities in the team results. With regard to objective and outcome criteria ( $\left.\mathrm{C}_{1}\right)$, the teams argue that the complexity of both projects is similar and is motivated by the interdependence between objectives: The aim of the GAL partnership formation is essential to achieve other objectives and results of regional programs. In addition to interdependence, teams believe that in both cases the goals are broad and multidimensional, to achieve an integrated approach to development: economic, physical capital, human capital and social capital development.

Factor in the case of stakeholders, integration (C2) factor, all teams considered high (3) complexity in the Madrid case, arguing that stakeholders are numerous and from different categories, the European Union, the National Government, the Madrid regional government, local governments and the private sector in the form of bonded Local Action Group. In the project Leader case in Mexico this factor increases the complexity (3.67), arguing the groups that relations between the parties were less familiar with divergent interests at the project beginning and the pressure groups existence against targets thereof. On this point, some reports quotes of learning teams of students are:

"Stakeholders are very numerous and from different categories. An important part is the GAL, the affected population formalization participation".

"At the beginning of the programme implementation, municipalities' interests were divergent on the model application."
Another similar result by groups is socio-cultural context assessing $\left(C_{3}\right)$. All groups agreed that according to this factor the Madrid project has a lower complexity (2), that of Mexico. The scope of the Mexico project is dispersed in five municipalities in the states of San Luis Potosi, State of Mexico and Veracruz. All teams agree that context diversity -territorial, social, ecological and political-, multiculturalism, geographic dispersion and social broad scope are aspects that affect the shares complexity. In the project areas different bio-geographical means are located -semiarid, highland, tropical forest evergreen- with different production systems and social ownership extension -from ejidos in the jungle, even ejidos in semi-arid zones. Moreover, the geographical distance between project teams is another area highlighted by all groups for their impact on complexity.

"Within the socio-cultural context, there are criteria that show high complexity, such as the social scope of the project, which is very broad."

Regarding the innovation grade ( $\left.\mathrm{C}_{4}\right)$, all teams agree in assessing both projects with high complexity (3.33). The reasons they argue, that the actions were aimed at finding new solutions to rural problems, promoting the diversification and multi-sectoral and multi-functional links. All teams emphasize that the main difficulty, for its innovation, has focused on the processes and actions to consolidate the $\mathrm{GAL}$, and new structures to manage projects. Creativity in the territories has been the basis for implementing rural innovation projects promoting new exploitation forms of resources and offering new products, -tourism, cultural and environmental tourism- reinforcing local identity. These actions have required technological innovations in relation to the recovery of local products, business creation and enhancement environmental heritage. Summaries from the reports are:

"The introduction of new working methods and constructing criteria for a endogenous development model, implies that the project development, the director and his team face the need to maintain an continues innovative approach" "Consider that the project has a high impact of public interest because the matter it develops."

About the factor analysis, project structure $\left(C_{5}\right)$, the teams agree in evaluate the Madrid project with medium complexity (2.67), while Mexico's case is evaluated as very high (3.67). The main arguments to assess the complexity are: the need for coordination between distant groups, between Spain and Mexico, and the new structures form need (GAL) on new concepts are to be coordinated. Furthermore, in the Mexico case, it has many multidimensional overlapping actions, from the formation of local structures for self-management, legalization of civil associations, skills acquisition processes and skills development for project management.

"The structures that must be coordinated are numerous, there are also many stakeholders involved, which increases the complexity"

Project organization (C6) is rated with a high complexity (3.33) in the Madrid case, and very high (3.67) in Mexico. The main arguments of this assessment are need for numerous teams in positions and responsibilities -in each of the GAL-, different structures and multiple decision-making processes. In the Mexico case, GAL was made -and local organizations for the projects management-, by different actors in the territory, - community representatives, city officers, City Councils, Municipal Councils for Sustainable Development, companies- with different interests and relationships. Each of these organizations defines their own distribution 
system of legal powers, its administrative rules, governance framework and management system.

Some quotes from the students learning teams reports are:

"The local action groups are regarded as subordinate in this case, raising enough the complexity degree, increasing the number of people, in unknown preparation, training or inclination"

"The structure team is multiple, no direct, so it becomes the project more complex"

"The style leadership is clearly multidimensional, although some basic guidelines are developed, then have to generate multiple decision nodes in the other institutions and groups involved."

The leadership, teamwork and making factor $\left(\mathrm{C}_{7}\right)$, also is measured with high complexity (3) in the Madrid case, and very high (3.67) in Mexico. In this case, indicate that learning from the program direction promotes a leadership style that respects the specificities of each GAL Governing Body in different areas, to achieve expression of the Association will to integrate all actors' partnership. These scenarios generate different teams and processes for decision making project. Some quotes from the students learning teams reports of are:

"The project forms part of rural development under a prism participatory and social learning. This implies an increase in the teamwork complexity between the various parties involved. Moreover, the idea behind the concept of partnership -translated Local Action Group- to build an alliance or association related to a common commitment to teamwork, make this factor has a high complexity." "In relation to decision making, identify complex interrelationships that increase the complexity of project management."
Regarding the resources factor (C8), it is noteworthy that the financial resources in the Leader model are oriented to find a local management, since the decisions decentralization and partnership local presence (Cazorla et al., 2005). In the Madrid case, to be EU funds managed from the GAL, the complexity is rated as low (2.33), while is a consensus that Mexico increases the complexity (3): funding resources for GAL projects must be achieved according to the allocation policies of each state. The availability of partners private resources must be managed with the project development companies in different ways, generating inaccurate and changes in their availability. The human resources availability -staffing requirements for the GAL operation- has a greater complexity in the Mexico case for the experience lack and diversity of contexts. In both cases, Madrid and Mexico, the GAL have a management team, -with an average size of 20 members-, with the main function of providing technical support to projects developers, prepare records and reports and monitor projects formulated from the organizations.

"While crews and technicians involved are permanent with a known configuration, the existence of a wide range of staff and the pursuit of public-private financing brings a complexity to the process."

Regarding the risks and opportunities factor: (C9) the complexity is rated low (2) in Madrid and high (3) in Mexico. After these years the implementing results of the Project Leader in Mexico, validate a new approach to management development based on social learning, and open opportunities to promote participatory processes. The novel notion of local action groups in Mexico, it is viewed as an great potential element for joint programs-rural development projects and building local capacity for genuine endogenous development. Some quotes from the students learning teams reports are:
"The risks in this project can be identified by the following: a) high number of parties involved and interested; b) The interrelationship and interdependence between the various parties, c) wide range of projects and action areas'

"With the model, there is an opportunity to change the way we manage rural development projects in Mexico and begin to develop the necessary methodologies to achieve the new policies and rural development programs success."

Finally, regarding the methods, tools and management techniques $\left(\mathrm{C}_{10}\right)$ the complexity is rated as medium-high (2.67). To facilitate coordination applied standards regarding how to manage the projects, followed. The GAL formation in Mexico has parallel developed with different methods and processes for acquiring skills and developing competences in project management; -Doctoral Program combined GESPLAN UPM-CP Planning and Project Management for Sustainable Development (2003-2010), Thematic Network on Professional Competencies for Participatory Development (2008-2010), IPMA LACC Project Plan Membership and Certification-, which has increased complexity. The availability of have technical assistance in the international aid context from the Spanish Agency for International Development (AECID), between years 2005-2010, is an added element which increases the complexity. Some quotes from the learning teams' students reports are:

"The management methods and tools are new to the concerned region. These tools for applying social learning model and partnerships creation, add an extra complexity in the project development you need to know to handle by the project manager."

The table 3 summarizes the assessment results of knowledge acquired by students after learning methodology. 


\begin{tabular}{|l|c|c|c|}
\hline & \multicolumn{3}{|c|}{ Level of knowledge } \\
\hline TECHNICAL COMPETENCES & INITIAL & FINAL & VARIATION \\
\hline No knowledge & $18 \%$ & $0 \%$ & $-18 \%$ \\
\hline Some basic knowledge & $42 \%$ & $18 \%$ & $-24 \%$ \\
\hline Average knowledge & $26 \%$ & $55 \%$ & $30 \%$ \\
\hline A good knowledge & $14 \%$ & $27 \%$ & $13 \%$ \\
\hline BEHAVIOURAL COMPETENCES & & & \\
\hline No knowledge & $6 \%$ & $0 \%$ & $-6 \%$ \\
\hline Some basic knowledge & $17 \%$ & $8 \%$ & $-9 \%$ \\
\hline Average knowledge & $51 \%$ & $50 \%$ & $-1 \%$ \\
\hline A good knowledge & $26 \%$ & $42 \%$ & $16 \%$ \\
\hline CONTEXTUAL COMPETENCES & & & \\
\hline No knowledge & $36 \%$ & $2 \%$ & $-34 \%$ \\
\hline Some basic knowledge & $39 \%$ & $23 \%$ & $-16 \%$ \\
\hline Average knowledge & $20 \%$ & $50 \%$ & $30 \%$ \\
\hline A good knowledge & $6 \%$ & $24 \%$ & $19 \%$ \\
\hline
\end{tabular}

Table 3: Summary of the evaluation of acquired knowledge by students

The program has a system of quality assurance, using learning valuation processes from the participants in the Masters. This process is structured around two axes: a process of continuous evaluation of students' individual character, a participatory assessment of character group to contrast and discuss individual assessments made collectively. It consists of two sessions, with students first and a second with the Master management team. Moreover since the European Commission, the program has been evaluated in the framework of Erasmus Mundus (ECOTEC, 2009). Analysis and reflection on the proposals and conclusions of this process can be drawn a series of "lessons learned" to keep improving the competencies integration in future editions. On the other hand it also performs an anonymous self-assessment -limited at program start and end-training activities- in order to verify the training process based on the NCB Competences and compare the results.

\section{Conclusions}

The concept of project management complexity is widely reported in international literature. However, the learning and training processes on project management complexity have received little attention. The methodology described is the result of an experience of Project
Based Learning (Project Base Learning) that has been validated and specifically suited for the development of technical, contextual and behavioral competences necessary to understand the key elements of project management complexity. The learning methodology links teaching with the professional background, and is founded in cooperation, active participation and interaction, offering multiple possibilities for the competence development in the global and international context.

Experience shows, as a first conclusion, that the success of a learning process focused on project management complexity is required to generate learning processes where students are not passive recipients of knowledge, but become engaged in an experience with real content. This pre-professional experience promotes students to integrate the knowledge they have learned and apply the new knowledge in a developed project.

A second conclusion would be the need to integrate processes and activities that help develop personal competences, learning to work together, enhancing their personality and bringing them closer to the reality of complex situations. These processes foster the spirit of innovative research and, creative abil- ity to generate new knowledge, increase their motivation and eagerness to learn and solve problems. The strategy and its instruments- agreements with institutions, PBL, STAR methodology, CIFTER, interaction with external actors- open new spaces for educational innovation and competence development (estimated $43 \%$ improvement), behavior (with a $15 \%$ improvement) and context (with a 49\% improvement).

As a third conclusion is that the EHEA and competency-based approach has shown to be an opportunity for educational innovation, establishing new connections among the university and professional world, taking as reference standards which are internationally recognized professional in the field of complexity project management. The fundamentals of GAPPS and the International Project Management Association (IPMA) are inserted into the higher education programs to facilitate this international framework of competence-based training. This integration also allows linking training with professional certification systems, offering greater employability of future graduates.

Finally, we emphasize the qualitative leap that has been made from isolated methodologies, with individual work on subjects by teachers to more global strategies, supported by complex structures and effective as Educational Innovation Program (EIP), linking research groups (GESPLAN) and groups of Innovative Education (GIE-project) which allows integration between teaching and applied research, developing a whole educational strategy from undergraduate to graduate level.

Moreover, from the assessments made during the evaluation process allow to draw some general conclusions from a series of "lessons learned" to refine the strategy. Main difficulties are related to competence assessment mainly for the different beliefs of each teacher, the greatest burden of work involved in on- 
going evaluation, and because students are not used to this evaluation system. It is highly valued and considered one of the main strengths the multidisciplinary and multicultural character of participants at Master's level enriched by the presence of professionals from various disciplines. The development of behavioral competence with cooperative learning activities is especially valued and considered necessary to successfully address the complexity of the projects.

\section{References}

AEIPRO. (2009). Bases para la competenia en Dirección de Proyectos. Versión 3.1. Valencia: Asociación Española de Ingeniería de Proyectos.

Allegre, L., Berlinguer, T., Blackstone, \& Rüttgers. (1998). Sorbonne joint declaration. Paris, May 1998: Communication, Ministers for France, Germany, Italy and United Kingdom.

Argyris, C., \& Schön, D. (1978).

Organisational Learning: A Theory of Action Perspective. Addison Wesley, Bostan, MA.

Baccarini, D. (1996). The concept of project complexity a review. International Journal of Project Management, Vol. 14, No. 4 , 201-204.

Bartkus, K. R. (2001). Skills and Cooperative Education: A conceptual Framework. Journal of Cooperative Education, Vol. 36, 17-24.

Bartkus, K. (2001). Skills and Cooperative Education: A conceptual Framework. Journal of Cooperative Education 36 (1), 17-24.

Bennett, J. (1991). International Construction Project Management: General Theory and Practice. Butterworth-Heinemann: Oxford.

Bennett, J; Fine, B. (1980). Measurement of Complexity in Construction Projects. Final Report of SERC Project GR/A/1342.4. University of Reading.

Bubshait, K., \& Selen, W. J. (1995). Project characteristics that influence the implementation of project management techniques: a survey. Project Management Journal XXIII (2) , 43-46.
Butts, C. (2001). The complexity of social networks: theoretical and empirical findings. Social Networks, $23,31-7$.

Cazorla, A., De los Ríos, I., \& Díaz-Puente, J. (2005). The Leader community initiative as rural development model: application in the capital region of Spain. Scientific Journal Agrociencia, vol. 39, núm. 6 , 697-708.

Cazorla, A., De los Ríos, I., Hernandez, D., \& Yagüe, J. (2010). Working with people (WWP): rural development project in communities aymaras of Peru. AGENG. International Conference on Agricultural Engineering. European Society of Agricultural Engineers. AGENG. International Conference on Agricultural Engineering. Clermont-Ferrand. France: European Society of Agricultural Engineers.

Checkland, P. (1989). Soft systems methodology. En C. 4, Rational analysis for a problematic world. Wiley.

Chinnowsky, P., Brown, A., Szajnman, \&

Realph, A. (2006). Developing Knowledge Landscapes through Project-Based Learning. Journal of Professional Issues in Engineering Education and Practice 132 (2) , 118-125.

Cicmil, S., \& Marshall, D. (2005). Insights into collaboration at project level: complexity, social interaction and procurement mechanisms. Build Res Inform , 33/6:523-35.

CIOB. (1991). Procurement and Project Performance. Occasional Paper No. 45. . England: Chartered Institute of Building (CIOB).

Cooke-Davies, T. (2004). De-engineering project management. . En Proceedings of the IRNOP VI conference (págs. 1-20). Turku, Finland.

Crawford, L. (2002). Profiling the competent project manager. En D. C. Slevin, The Frontiers of Project Management Research. (págs. 151-176). Pennsylvania: Project Management Institute, Newtown Square.

Crawford, L. (2005). Senior management perceptions of project management competence. International Journal of Project Management 23 (1) , 7-16.
Crawford, L., Costello, K., Pollack, J., \& Bentley, L. (2003). Managing soft change projects in the public sector. International Journal of Project Management 21 (6), 443-448.

Davies, A., \& Hobday, M. (2005). The business of projects. Cambridge University Press.

De los Ríos, I., Cazorla, A., J.M., D.-P., \& Yagüe, J. (2010). Project-based learning in engineering higher education: two decades of teaching competences in real environments. Procedia: Social and Behavioral Sciences .

De los Ríos, I.; Ros, A.; Ortiz, I.; Fernández, A.; Del Río, M.; A., Romera. (2010). Cooperative model for learning and assessment of behavioural competences in project management according to IPMA-NCB model. Selected Proceedings 13th International Congress on Project Engineering (págs. 134-146). AEIPRO. International Project Management Association (IPMA).

De los Ríos, I; Ortiz Marcos, I.; Díaz-Puente, J.M. (2008). Project management teaching in engineering higher education: A new perspective for developing competencies. Zaragoza: AEIPRO.

De los Ríos-Carmenado, I.; Ortiz, I.; DíazPuente, J. (2009). Project management teaching in engineering higher education: A new perspective for developing competencies. Selected Proceedings 12th International Congress on Project Engineering (págs. 418-427). AEIPRO. International Project Management Association (IPMA).

ECOTEC. (2009). Ex-post evaluation of Erasmus Mundus. Case Studies. AGRIS MUNDUS, Sustainable Development in Agriculture .

European Commission . (1999). The Bologna declaration. Bologna, Italy: Communication, European Commission, Directorate-General for Education and Culture.

European Commission. (2000). A memorandum on lifelong learning. Memorandum SEC(2000) 1832 . Brusssels, October 2000: European Commission,. 
European Commission. (2003). Conference of Berlin. Berlin, September 2003: Communication, European Commission, Ministers responsible for Higher Education.

European Commission. (2001). Making a european area of lifelong learning reality. Communication COM(2001) 678 final. Brussels: European Commission, Directorate-General for Education and Culture and Directorate-General for Employment and Social A airs.

European Council. (2000). Agree a new strategic goal. . Lisbon, Portugal, March 2000: Communication DOC/0o/8, European Union.

Flyvbjerg, B. (2002). Underestimating costs in public works projects. Error or lie? Am Plan Assoc J , 68(3):279-95.

Galbraith, J. (1973). Designing complex organisations. Reading,. MA: AddisonWesley.

GAPPS. (2007). A Framework for Performance Based Competency Standards for Global Level 1 and 2 Project Managers. Sydney: Global Alliance for Project Performance Standards.

Gareis, R. (2010). Designing changes of permanent organizations by processes and projects. International Journal of Project Management 28 (4) , 314-327.

Gijselaers, W. H. (1996). Connecting problembased learning with educational theory. En Bringing problem-based learning to higher education: Theory and practice, (págs. 13-21). San Francisco: Jossey-Bass: eds. L. Wilkerson and W. H. Gijselaers.

Hackett, R., Martin, G., \& Rosselli, D. (1998). Factors Related to Performance Ratings of Engineering Students in Cooperative Education Placements. Journal of Engineering Education 87(4), 445-458.

Hodgson, D. (2002). Disciplining the professional: the case of project management . J Manage Stud , 39(6):80321.

Hodgson, D; Cicmil, S. (2006). Making projects critical. Palgrave Macmillan.

Hughes, M. (2007). The tools and techniques of change management. Journal of Change Management 7 (1), 37-49.

IPMA. (2008). IPMA Certification Yearbook.
IPMA, International Project Management Association. Editors: Werner Schmehr, Hans Knoepfel. www.ipma.ch/ certification.

IPMA, I. P. (2009). IPMA Certification Yearbook 2009. Editors: Werner Schmehr, Hans Knoepfel.

ISO/IEC:17024. (2003). Conformity assessment. General requirements for bodies operating certification of persons. Switzerland: International Organization for Standardization.

Johnson, P. (1999). Project-Based, cooperative learning in the engineering classroom. Journal of Professional Issues in Engineering Education and Practice 125 (1) , 8-11.

Kelly, W. (2007). Certification and Accreditation in Civil Engineering. Journal of Professional Issues in Engineering Education and Practice 133(3) , 181-187.

Korten, D. C. (1980). Community organization and rural development: $\mathrm{A}$ learning process approach. Public Administration Review (September/October).

Lawrence, P., \& Lorsch, J. (1967). Organisation and environment: managing integration and differentiation. Boston: Harvard University.

Linehan, C., \& Kavanagh, D. (2004). From project ontologies to communities of virtue. 2nd Workshop of Making Projects CriticalBristol, UK, 1-15.

López, M., Martínez-Almela, J., \& Capuz-Rizo, J. (2009). Análisis del rol del director del proyecto en el marco de la complejidad de los proyectos. Actas del Congreso Internacional de Ingeneiría de Proyectos AEIPRO-IPMA. Badajoz 2009: AEIPRO Congress Proceedings.

Martinez-Almela, J., NCB3.Bases para la competencia en dirección de proyectos $V_{3}$ (2006) V3.1(2009) AEIPRO-OCDP. Editorial UPV, Valencia, Spain.

Miller, R., \& Lessard, D. (2001). The strategic management of large engineering projects: shaping institution. MIT Press.

Morris, P. (2006). Exploring the role of formal bodies of knowledge in defining a profession - The case of project management. International Journal of Project Management, $24,710-21$.
Morris, P. (2002). Science, objective knowledge and the theory of project management. Civil Eng Proc ICE , 150:8290.

Morris, P. W., \& Hough, G. H. (1987). The Anatomy of Major Projects. Wiley, Chichester.

Morris, P; Hough, G. (1987). The anatomy of major projects. Wiley.

Morris, P; Pinto, J. (2004). The Wiley guide to managing projects. New Jersey: Wiley.

Mulcahy, D. (2000). Turning the contradictions of competence: competence-based training and the beyond. Journal of Vocational Education and Training 52 (2) , 259-280.

Müller, R., \& Turner, R. (2010). Leadership competency profiles of successful project managers . International Journal of Project Management 28 , 437-448.

Nieminen, A., \& Lehtonen, M. (2008). Organisational control in programme teams: an empirical study in change programme context: European Academy of Management (EURAM 2007) conference. International. Journal of Project Management 26 (1) , 63-72.

Nikolaou, I., Gouras, A., Vakola, M., \& Bourantis, D. (2007). Selecting change agents: exploring traits and skills in a simulated environment. Journal of Change Management 7 (3/4) , 291-313.

Ojiako, U., Ashleigh, M., Chipulu, M., \& Maguire, M. (2011). Learning and teaching challenges in project management. International Journal of Project Management, 29 (3) , 268-278.

Padmanadhan, G., \& Katti, D. (2002). Using community-based projects in civil engineering capstone courses. Journal of Professional Issues in Engineering Education and Practice 125 (1) , 12-18. Parsons, C., Caylor, E., \& Simmons, $\mathrm{H}$. (2005). Cooperative Education Work Assignments The role of Organizational and Individual Factors in Enhancing ABET Competencies and Cp-op Workplace WellBeing. Journal of Engineering Education 94(3) , 309-316.

Patton, M. Q. (1997). Utilization-Focused Evaluation: The New Century Text, 3rd ed. Thousand Oaks, CA: Sage. 
Pellegrinelli, S. (1997). Programme management: organising project-based change. International Journal of Project Management Vol. 15, No. 3, 141-149.

Preskill, H., \& Torres, R. (1999). Evaluative Inquiry for Learning in Organization. Thousand Oaks, CA: Sage Publications.

Rondinelli, D. A. (1993). Development Projects as Policy Experiments: An Adaptive Approach to Development Administration. London: Routledge (2nd edn).

Sánchez Nuñez, J. (1996). Los métodos de enseñanza. Curso superior de formación para la docencia universitaria. Madrid: ICE-UPM.

Selznick, P. (1957). Leadership in Administration. New York: Evanston, Peterson and $\mathrm{Co}$.

Stinchcombe, A., \& Heimer, C. (1985). Organization theory and project management, administering uncertainty.
Norwegian offshore oil. Oslo: Norwegian University Press.

Turner, J. (1996). International Project Management Association global qualification, certification and accreditation. International Journal of Project Management, 14 (1), Pages 1-6. . Turner, J.R.; Grude, K.V.; Thurloway, L. (1996). The Project Manager as Change Agent: Leadership Influence and Negotiation. London: McGraw-Hill.

Uhl-Bien, M., Marion, R., \& McKelvey, B. (2007). Complexity Leadership Theory: Shifting leadership from the industrial age to the knowledge era. The Leadership Quarterly 18, 298-318.

Uphoff, N. (1990). Paraprojects as new modes of international development assistance. World Development 18 .

UPM. (2006). Normativa de Reconocimiento de Grupos de Innovación Educativa de la Universidad Politécnica de Madrid.
Madrid: Consejo de Gobierno de la Universidad Politécnica de Madrid. .

Whyte, W. F. (1991). Participatory Action Research. Newbury Park, CA: Sage.

Williams, T. (2002). Modelling complex projects. Wiley.

Winch, G. (2004). Rethinking project management: project organizations as information processing systems? Proceedings of the PMI research conference, July 2004. London: Project Management Institute.

Winter, M., Smith, C., Morris, P., \& Cicmil, S. (2006). Directions for future research in project management: The main findings of a UK government-funded research network. International Journal of Project Management, 24 , 638-649.

Yeo, K. (1993). Systems thinking and project management - time to reunite. Int J Project Manage , 11(2):1-7. 